\title{
Chemical composition and larvicidal activity of essential oils from Nepeta cadmea Boiss. and Pimpinella anisum L. on the larvae of Culex pipiens $\mathrm{L}$.
}

\author{
Emre Öz ${ }^{1}$, Samed Koç ${ }^{1}$, İlker Çinbilgel ${ }^{2}$, Atila Yanıkoğlu ${ }^{1}$ and Hüseyin Çetin 1, * \\ 1 Department of Biology, Faculty of Science, Akdeniz University, Antalya, Turkey. \\ 2 Department of Tourism Guidance, Manavgat Tourism Faculty, Akdeniz University, Antalya, Turkey. \\ * Correspondence: hcetin@akdeniz.edu.tr (H.Ç.); Tel: +90 24231022 86; Fax: +90 24222789 11; ORCID No: 0000- \\ 0002-9758-6356.
}

Received: 20 October 2017; Revised: 17 December 2017; Accepted: 21 December 2017

\begin{abstract}
Culex pipiens L. (Diptera: Culicidae) is an important vector of West Nile virus in many parts of the world. In this research, the essential oils obtained from Nepeta cadmea Boiss. (endemic for Turkey) and Pimpinella anisum L. were examined for larvicidal activity against second-third instar larvae of $C x$. pipiens. The essential oils were distilled from aerial parts of $N$. cadmea and seeds of $P$. anisum by water distillation. The chemical composition of these oils was determined by gas chromatography-mass spectrometry (GC-MS). The lethal concentration 50 and 90 values of these essential oils were 28.7 and $49.51 \mathrm{ppm}$, and 39.82 and $74.57 \mathrm{ppm}$, respectively. As a result, both essential oils were found highly toxic to larvae of $C x$. pipiens. Our results showed that the essential oils obtained from $N$. cadmea and $P$. anisum may be suitable for the development of potential new botanical insecticides.
\end{abstract}

KEYWORDS: Mosquito Larvae, Nepeta cadmea, Pimpinella anisum, Toxicity

\section{INTRODUCTION}

Mosquitoes (Diptera: Culicidae) are important vectors of many diseases such as dengue fever, malaria, yellow fever, West Nile fever and Zika [1,2]. Anopheles, Aedes and Culex are most abundant and important genera of mosquitoes which have over 3000 species worldwide. Mosquito fauna of Turkey consists of 54 species [3,4]. In Turkey, Culex pipiens L. is usually the most common mosquito in urban and suburban areas and lives in polluted water; often in septic tank systems [5]. This insect has been implicated as vector of arboviruses including St. Louis encephalitis and West Nile fever [6].

The combination of biological, cultural, mechanical-physical and chemical control methods are known as integrated pest management [7]. Using of chemicals is among the most commonly used methods to control mosquitoes. The frequent and improper usage of these pesticides can cause a variety of adverse health problems in humans and animals and also an increase in resistance. Also, some insecticides may be harmful to the non-target organisms such as fishes, predators and honey bees [8,9]. Control of insecticide resistant mosquitoes becomes more difficult day by day. Insecticides within botanical origin may serve as suitable and efficient natural products. Most botanicals are safer than synthetic insecticides and less harmful to non-target organisms [10]. Therefore, the present study aims to evaluate the larvicidal activity of essential oils obtained from Pimpinella anisum L. and Nepeta cadmea Boiss. under laboratory conditions against second-third instar larvae of $C x$. pipiens which is an important vector of West Nile fever. The essential oil of endemic N. cadmea (aerial parts) has not been the subject of any research, and this study is the first report in this regard.

How to cite this article: Öz E, Koç S, Çinbilgel I, Yanıkoğlu A, Çetin H. Chemical composition and larvicidal activity of essential oils from Nepeta cadmea Boiss. and Pimpinella anisum L. on the larvae of Culex pipiens L. Marmara Pharm J. $2018 ; 22$ (2): $322-327$. 


\section{RESULTS}

The list of essential components and the percentage composition of both oils are shown in Table 1 . The essential oils were extracted from the seeds of P. anisum and aerial parts of $N$. cadmea at yields of $2.95 \%$ and $1.86 \%$, respectively. Eighteen components in endemic N. cadmea $(94.48 \%)$ were identified and Caryophyllene oxide $(22.96 \%)$, Viridiflorol $(12.23 \%)$, cis-Calamenene $(10.67 \%)$, cis-14-nor-Muurol-5-en-4-one $(7.53 \%)$, aCadinol (6.92\%) and Caryophylla-4(12),8(13)-dien-5- $\beta$-ol (6.11\%) were identified as the major components. In the essential oil $P$. anisum four components were identified, which represent $100 \%$ of the total composition and the major component was anethole $(94.48 \%)$.

Table 1. Essential oil compositions of Pimpinella anisum seeds and Nepeta cadmea aerial parts.

\begin{tabular}{|c|c|c|}
\hline \multicolumn{3}{|c|}{ Essential Oil Composition of Pimpinella anisum seeds } \\
\hline Retention Times (Min) & Compounds & Area $(\%)$ \\
\hline 36.802 & p-Allylanisole & 2.77 \\
\hline 37.701 & $\gamma$-Himachalene & 0.41 \\
\hline 41.364 & Anethole & 94.16 \\
\hline 46.679 & Anisaldehyde & 2.66 \\
\hline & Total & 100 \\
\hline \multicolumn{3}{|c|}{ Essential Oil Composition of Nepeta cadmea aerial parts } \\
\hline Retention Times (Min) & Compounds & Area $(\%)$ \\
\hline 31.235 & a-Copaene & 1.15 \\
\hline 32.66 & Linalool & 4.05 \\
\hline 34.739 & $\beta$-Caryophyllene & 4.39 \\
\hline 37.399 & $\gamma$-Cadinene & 0.89 \\
\hline 39.485 & a-Amorphene & 2.43 \\
\hline 41.511 & cis-Calamenene & 10.67 \\
\hline 45.797 & Caryophyllene oxide & 22.96 \\
\hline 46.74 & Ledol & 1.75 \\
\hline 47.101 & cis-trans Nepetalactone & 3.09 \\
\hline 47.306 & 1,10-di-epi-Cubenol & 2.12 \\
\hline 47.964 & Viridiflorol & 12.23 \\
\hline 48.841 & Spathulenol & 2.70 \\
\hline 49.395 & Alloaromadendrene oxide & 2.34 \\
\hline 49.854 & Zonarene & 1.12 \\
\hline 51.33 & $a$-Cadinol & 6.92 \\
\hline 53.074 & Caryophylla-4(12),8(13)-dien-5- $\beta$-ol & 6.11 \\
\hline 53.552 & cis-14-nor-Muurol-5-en-4-one & 7.53 \\
\hline \multirow[t]{2}{*}{54.907} & 13-Epimanoyl oxide & 2.03 \\
\hline & Total & 94.48 \\
\hline
\end{tabular}

According to our results, both essential oils were highly toxic for larvae of $C x$. pipiens. The essential oil obtained from N. cadmea showed larvicidal activity as strong as that of P. anisum essential oil. $\mathrm{LC}_{50}$ and $\mathrm{LC}_{90}$ values of N. cadmea were found 39.8 and $74.5 \mathrm{ppm}$ to $C x$. pipiens after $48 \mathrm{~h}$ exposure, respectively (Table 2). In general, there was a direct correlation between concentrations and mortalities. Concentrations of $\geq 100 \mathrm{ppm}$ led to $100 \%$ mortality, while concentration of $50 \mathrm{ppm}$ had moderate toxic effect to $C x$. pipiens at $48 \mathrm{~h}$ (Table 3).

After $48 \mathrm{~h}$ exposure period $\mathrm{LC}_{50}$ and $\mathrm{LC}_{90}$ values for P. anisum essential oil were $28.7 \mathrm{ppm} 49.51 \mathrm{ppm}$, respectively (Table 2). Whereas concentrations of 10 and $25 \mathrm{ppm}$ had low toxicity, concentrations of $\geq 50 \mathrm{ppm}$ caused $100 \%$ mortality after $48 \mathrm{~h}$ exposure (Table 3). 
Table 2. $\mathrm{LC}_{50}$ and $\mathrm{LC}_{90}$ values (ppm) of tested essential oils for second-third instar larvae of Culex pipiens after $48 \mathrm{~h}$ exposure.

\begin{tabular}{ccc}
\hline Test plants & LC $_{50}(\mathrm{LL}-\mathrm{UL})^{\mathrm{a}}$ & LC $_{\mathbf{9 0}}[\mathrm{LL}-\mathrm{UL})$ \\
\hline Pimpinella anisum & $28.7(17.25-47.75)$ & $49.5(23.5-104.32)$ \\
Nepeta cadmea & $39.8(21.31-67.66)$ & $74.5(49.69-493.48)$ \\
\hline
\end{tabular}

a95 \% fiducial limits; $\mathrm{LL}=$ lower limit; $\mathrm{UL}=$ upper limit ppm= parts per million
$\mathrm{LC}_{50}=$ Lethal concentration at which $50 \%$ of the larvae showed mortality.
$\mathrm{LC}_{90}=$ Lethal concentration at which $90 \%$ of the larvae showed mortality.

Table 3. Larvicidal activity of Pimpinella anisum and Nepeta cadmea essential oils against second-third instar larvae of Culex pipiens (Percent mortalities \pm SE) after $48 \mathrm{~h}$ exposure.

\begin{tabular}{ccc}
\hline Test Concentrations (ppm) & Pimpinella anisum & Nepeta cadmea \\
\hline Control & $0.0 \pm 0.0 \mathrm{a}^{\mathrm{x}}, \mathrm{Ay}$ & $0.0 \pm 0.0 \mathrm{a}, \mathrm{A}$ \\
10 & $6.68 \pm 6.68 \mathrm{ab}, \mathrm{A}$ & $3.33 \pm 3.33 \mathrm{a}, \mathrm{A}$ \\
25 & $16.67 \pm 8.83 \mathrm{~b}, \mathrm{~A}$ & $10.0 \pm 5.78 \mathrm{a}, \mathrm{A}$ \\
50 & $100 \mathrm{c}, \mathrm{A}$ & $66.67 \pm 13.35 \mathrm{~b}, \mathrm{~B}$ \\
100 & $100 \mathrm{c}, \mathrm{A}$ & $100 \mathrm{c}, \mathrm{A}$ \\
200 & $100 \mathrm{c}, \mathrm{A}$ & $100 \mathrm{c}, \mathrm{A}$ \\
400 & $100 \mathrm{c}, \mathrm{A}$ & $100 \mathrm{c}, \mathrm{A}$ \\
\hline
\end{tabular}

$\mathrm{x}$ : Means within a column for each concentration followed by the same letter are not significantly different $(\mathrm{P}>0.05)$.

$\mathrm{y}$ : Means within a line for each concentration followed by the same letter are not significantly different $(\mathrm{P}>0.05)$.

\section{DISCUSSION}

According to our literature survey, this is the first study to show toxic effect of essential oils obtained from $N$. cadmea on $C x$. pipiens larvae, but scientists studied about the toxicity of other Nepeta species on important mosquito species. For example, Mahnaz et al. [11] showed that essential oil and methanol extract of the N. menthoides have larvicidal effect on malaria vector, Anopheles stephensi. The reported $\mathrm{LC}_{50}$ values were 69.5 and $234.3 \mathrm{ppm}$ and $\mathrm{LC}_{90}$ values were 175.5 and $419.9 \mathrm{ppm}$ for the extract and essential oil respectively. Abbas et al. [12] reported that essential oils of four Nepeta species showed weak larvicidal activity on Aedes aegypti. Sathantriphop et al. [13] reported that $N$. cataria (catnip) essential oil had very toxic effects on $A$. aegypti and An. minimus.

We found that there is only one research about the larvicidal activity of $P$. anisum against $C x$. pipiens. In this research, $P$. anisum essential oil showed high larvicidal activity to $C x$. pipiens with $\mathrm{LC}_{50}$ and $\mathrm{LC}_{90}$ values were 15.24 and $23.79 \mathrm{mg} / \mathrm{L}$ after $24 \mathrm{~h}$ exposure [14]. Toxic effects of $P$. anisum essential oil were tested in the different life stages of some other mosquito species. $P$. anisum essential oil showed high toxic activity against fourth instar larvae of An. stephensi, A. aegypti and Cx. quinquefasciatus with LD 95 rates of 115.7, 115.7 and 149.7 $\mu \mathrm{g} / \mathrm{mL}$, respectively [15]. Pavela [16] examined toxic effects of $P$. anisum essential oil and its major compound (trans-anethole) on different life stages of $C x$. quinquafasciatus. This researcher found that $\mathrm{LC}_{50}$ values for oil and major compound were $26-27 \mu \mathrm{L} / \mathrm{L}$ and $15-19 \mu \mathrm{L} / \mathrm{L}$ to second and fourth instar larvae, respectively. Knio et al. [17] found that P. anisum seed oil had toxic to larvae of Ochlerotatus caspius Pallas. and $\mathrm{LC}_{50}$ and LC 90 values were 65 and $137 \mu \mathrm{g} / \mathrm{mL}$, respectively. Erler et al. [18] tested some essential oils including the P. anisum for repellency on $C x$. pipiens adults.

In addition to, there are many reports about repellent and fumigant toxicity, and also attractiveness of P. anisum essential oil on some other pest species. For example, Mikhaiel [19] reported that anise oil causes complete mortality to Ephestia kuehniella and Tribolium castaneum adults at $64 \mu \mathrm{l} / \mathrm{L}$ air concentration within $24 \mathrm{~h}$. Robles-Bermúdez et al. [20] searched the effect of blue traps impregnated with anise fruit extract for capturing thrips. Cevik and Erler [21] researched fumigant activity of some essential oils and their major components (trans-anethole, eucalyptol, menthol, carvacrol and thymol, respectively) against the adult mushroom cecid flies and found that 20 and $40 \mu \mathrm{L} / \mathrm{L}$ air concentrations of the all essential oils and components (except for trans-anethole and menthol at an exposure period of $1 \mathrm{~h}$ ) showed 100\% mortality. Elma and Alaoglu [22] studied the toxicity of methanol extracts of eight plants that include $P$. anisum, on nymphs of Eurygaster maura L. They reported that young nymphs were more sensitive than olds. Nenaah and Ibrahim 
[23] found that a dose of $1.50 \mathrm{~mL} / \mathrm{cm}^{2}$ of the P. anisum oil gave $100 \%$ and $92 \%$ mortalities on T. castaneum and Trogoderma granarium (Everts) adults after 14 days exposure period, respectively.

Erler and Cetin [24] reported that anise oil and trans-anethole produced $89.0 \%$ and $100 \%$ larval mortality on the brown-tail moth, Euproctis chrysorrhoea L., respectively, at $96 \mathrm{~h}$ at a concentration of $0.5 \%$. Khater et al. [25] investigated toxicity of essential oils of lettuce (Lactuca sativa), chamomile (Matricaria chamomilla), anise ( $P$. anisum) and rosemary (Rosmarinus officinalis) against the larva of Lucilia sericata. $\mathrm{LC}_{50}$ values were found as $0.57 \%, 0.85 \%, 2.74 \%$, and $6.77 \%$ for lettuce, chamomile, anise and rosemary oils, respectively. Isıkber et al. [26] studied susceptibility of eggs of Tribolium confusum du Val., Ephestia kuehniella and Plodia interpunctella (Hübner) to vapors of essential oil from garlic, birch, cinnamon and anise and they reported that garlic and birch essential oils were more toxic than cinnamon and anise essential oils. Erler et al. [27] reported that $P$. anisum seed extract caused a significant decline in mushroom pest (Megaselia halterata) adult emerhgence rate. Tunç et al. [28] examined the fumigant toxicity of $P$. anisum essential oil against to eggs of $T$. confusum and $E$. kuehniella. The exposure to vapour of this essential oil was found highly toxic to eggs.

In previous researches anethole was recorded as major compound in P. anisum seed oil. The ratio of this compound may be shown variations (more than $93 \%$ ) according to the collection localities, climatic conditions and distillation methods [29]. In this study the larvicidal action of anise oil has been attributed to anethole that was previously found toxic to many pest species [21,24]. According to our results N. cadmea essential has many major and minor compounds. We suppose that the larvicidal activity of $N$. cadmea essential oil is attributed to the presence of the number of compounds (both minor and major), their percentage in the oil and synergistic interactions between the compounds.

As a result, both essential oils showed high larvicidal activity on $C x$. pipiens larvae and exhibited significant concentration-dependent larvicidal activity. Based on these results, P. anisum and N. cadmea essential oils may be a candidate for the development of new botanical insecticides applied to $C x$. pipiens larvae but further studies are needed.

\section{MATERIALS AND METHODS}

\subsection{Mosquito culture}

The mosquito, $\mathrm{C} x$. pipiens, used in tests was originated a pool from field areas of Antalya in Turkey and has been reared $24 \pm 2^{\circ} \mathrm{C}$ and $50 \pm 10 \%$ relative humidity with 10:14 dark:light photoperiod conditions more than seven years in the Vector Control and Ecology Laboratory, Department of Biology, Akdeniz University in Antalya. Second-third instar larvae of mosquito were used in the larvicidal activity tests.

\subsection{Collection of plant materials}

Pimpinella anisum seeds were purchased from a market in Antalya. The aerial parts of N. cadmea in the flowering period were collected from Antalya, Turkey (N 37॰14'931"- E31' 24'420", altitude 1255) in July. The third author of this paper did taxonomic identification of plants according to Davis [30] and Güner et al. [31] and then voucher specimens (Çinbilgel 8029) were deposited in the laboratory.

\subsection{Isolation of essential oils and determination of chemical compositions}

Pimpinella anisum seeds and the aerial parts of N. cadmea were cleaned and dried in shadow for 3 weeks and powdered by a mechanical grinder. Dried plants were put in to the flask with enough water and distilated for $3 \mathrm{~h}$ by using a Clevenger-type apparatus. Obtained essential oils were put in glass tubes $(10 \mathrm{ml})$ and stored at $4^{\circ} \mathrm{C}$ refrigerator until tested.

The chemical analysis was carried out on a Agilent 7890A GC/MS using a HP-5 capillary column (30 m $\times 0.25 \mathrm{~mm} \times 0.25 \mathrm{~mm}$ ); carrier gas helium, flow rate $0,8 \mathrm{~mL} \mathrm{~min}^{-1}$. The injection volume was $1 \mu \mathrm{L}$. The injector temperature was $250^{\circ} \mathrm{C}$. The initial oven temperature was set at $60^{\circ} \mathrm{C}$ and held for $10 \mathrm{~min}$, then programmed from $60^{\circ} \mathrm{C}$ to $220^{\circ} \mathrm{C}$ at $4^{\circ} \mathrm{C} \mathrm{min}^{-1}$ and then $220^{\circ} \mathrm{C}$ at $10 \mathrm{~min}$. The mass spectrometer was operated in electron impact (EI) mode with the ionization energy of $70 \mathrm{eV}$. Full mass scan of 35-480 amu was used. Compounds were identified by comparing their mass spectrum to those of the database of the GC-MS (Oil Adams and Wiley), literature and retention indices. 


\subsection{Larvicidal activity tests}

Larvicidal toxicity tests were made according to the method described by Cetin and Yanikoglu [32]. For the stock solution, $0.5 \mathrm{ml}$ essential oil was dissolved in $500 \mathrm{ml}$ distilled water using Tween $80(0.3 \%)$. Six test concentrations $(10,25,50,100,200,400 \mathrm{ppm})$ of dissolved essential oils were prepared from stocks. Distilled water containing $0.3 \%$ Tween 80 was used as control group. After five minutes, ten larvae were released to plastic containers. Three replicates of each concentration were established and mortality values were recorded after $48 \mathrm{~h}$ of exposure. Larvae were daily fed with fish food. Dead larvae were identified when they failed to move after probing with a needle in the siphon or cervical region. All tests were conducted at $24 \pm 2{ }^{\circ} \mathrm{C}$ and $50 \pm 10 \%$ relative humidity with 10:14 dark:light photoperiod conditions.

\subsection{Statistical Analysis}

Lethal concentration $\left(\mathrm{LC}_{50}\right.$ and $\mathrm{LC}_{90}$ ) values were determined by probit analysis. All percent mortalities analyzed using Statistical Analysis System ANOVA [33]. Mean mortalities were compared with Duncan's multiple range test.

Acknowledgements: The authors thank the Scientific Research Projects Committee Unit of Akdeniz University for financial support.

Author contributions: Concept - E.Ö., S.K., İ.Ç., A.Y., H.Ç.; Design - E.Ö., S.K., İ.Ç., A.Y., H.Ç.; Supervision - E.Ö., S.K., İ.Ç., A.Y., H.Ç.; Resource - E.Ö., S.K., İ.Ç., A.Y., H.Ç.; Materials - E.Ö., S.K., İ.Ç., A.Y., H.Ç.; Data Collection and/or Processing - E.Ö., S.K., İ.Ç., A.Y., H.Ç.; Analysis and/or Interpretation - E.Ö., S.K., İ.Ç., A.Y., H.Ç.; Literature Search E.Ö., S.K., İ.Ç., A.Y., H.Ç.; Writing - E.Ö., S.K., İ.Ç., A.Y., H.Ç.; Critical Reviews - E.Ö., S.K., İ.Ç., A.Y., H.Ç.

Conflicts of Interest: The authors declare that they have no competing interests.

\section{REFERENCES}

[1] Benelli G, Mehlhorn H. Declining malaria, rising of dengue and Zika virus: insights for mosquito vector control. Parasitol Res. 2016; 115(5):1747-1754.

[2] Li XF, Han JF, Shi PY, Qin CF. Zika virus: a new threat from mosquitoes. Sci China Life Sci 2016; 59(4): 440-442.

[3] Ramsdale CD, Alten B, Caglar SS, Ozer N. A revised, annotated checklist of the mosquitoes [Diptera, Culicidae] of Turkey. Eur Mosq Bull. 2001; 9:18-28.

[4] Günay F, Alten B, Simsek F, Aldemir A, Linton YM. Barcoding Turkish Culex mosquitoes to facilitate arbovirus vector incrimination studies reveals hidden diversity and new potential vectors. Acta Trop. 2015; 143:112-120.

[5] Cetin H, Yanikoglu A. Mosquito (Diptera: Culicidae) species, their breeding sites and some biological aspects of dominant species Culex pipiens L. in Antalya, Turkey. Turkish J Entomol. Derg. 2004; 28(4): 283-294.

[6] Andreadis TG, Armstrong PM, Bajwa WI. Studies on hibernating populations of Culex pipiens from a West Nile virus endemic focus in New York City: Parity rates and isolation of West Nile virus. J Am Mosq Control Assoc. 2010; 26: 257-264.

[7] Rose RI. Pesticides and public health: integrated methods of mosquito management. Emerg Infect Dis. 2001; 7(1):1723.

[8] Wirth MC. Mosquito resistance to bacterial larvicidal toxins. Open Toxicol J. 2010; 3:126-140.

[9] Ser Ö, Cetin H. Toxicity of mosquito larvicides on non-target mosquito predator insect backswimmer (Notonecta sp.). Fres Environ Bull. 2015; 24:311-316.

[10] Pavela R, Govindarajan M. The essential oil from Zanthoxylum monophyllum a potential mosquito larvicide with low toxicity to the non-target fish Gambusia affinis. J Pest Sci. 2017; 90(1):369-378.

[11] Mahnaz K, Alireza F, Hassan V, Mahdi S, Reza AM, Abbas H. Larvicidal activity of essential oil and methanol extract of Nepeta menthoides against malaria vector Anopheles stephensi. Asian Pac J Trop Med. 2012; 5: 962-965.

[12] Abbas A, Tabanca N, Demirci B, Blythe EK, Baser KHC, Khan IA. Chemical composition and biological activity of essential oils from four Nepeta species and hybrids against Aedes aegypti (L.) (Diptera: Culicidae). Rec Nat Prod. 2016; 10(2):137-147. 
[13] Sathantriphop S, Achee NL, Sanguanpong U, Chareonviriyaphap T. The effects of plant essential oils on escape response and mortality rate of Aedes aegypti and Anopheles minimus. J Vector Ecol. 2015; 40:318-326.

[14] Kimbaris AC, Koliopoulos G, Michaelakis A, Konstantopoulou MA. Bioactivity of Dianthus caryophyllus, Lepidium sativum, Pimpinella anisum, and Illicium verum essential oils and their major components against the West Nile vector Culex pipiens. Parasitol Res. 2012; 111(6):2403-2410.

[15] Prajapati V, Tripathi AK, Aggarwal KK, Khanuja SPS. Insecticidal, repellent and oviposition-deterrent activity of selected essential oils against Anopheles stephensi, Aedes aegypti and Culex quinquefasciatus. Bioresour Technol. 2005; 96(16):1749-1757.

[16] Pavela R. Insecticidal properties of Pimpinella anisum essential oils against the Culex quinquefasciatus and the nontarget organism Daphnia magna. J Asian Pac Entomol. 2014; 17(3):287-293.

[17] Knio KM, Usta J, Dagher S, Zournajian H, Kreydiyyeh S. Larvicidal activity of essential oils extracted from commonly used herbs in Lebanon against the seaside mosquito, Ochlerotatus caspius. Bioresour Technol. 2008; 99(4):763-768.

[18] Erler F, Ulug I, Yalcinkaya B. Repellent activity of five essential oils against Culex pipiens. Fitoterapia. 2006; 77(78):491-494

[19] Mikhaiel AA. Potential of some volatile oils in protecting packages of irradiated wheat flour against Ephestia kuehniella and Tribolium castaneum. J Stored Prod Res. 2011; 47(4):357-364.

[20] Robles-Bermúdez A, Santillán-Ortega C, Rodríguez-Maciel JC, Gómez-Aguilar JR, Isiordia-Aquino N, PérezGonzález R. Traps Treated with Pimpinella anisum, as attractant of thrips (Thysanoptera:Thripidae) in rose. Rev Mex Cienc Agric. 2011; 2(3):555-563.

[21] Cevik T, Erler F. Fumigant activity of some plant essential oils and their main components against mushroom cecid flies (Diptera: Cecidomyiidae). Fres Environ Bull. 2014; 23(8):2002-2010.

[22] Elma FN, Alaoğlu Ö. Toxicity of some plant extracts to various nymphal stages of Eurygaster maura L. (Heteroptera: Scutellaridae). Turkish J Entomol. 2014; 38(2):181-188.

[23] Nenaah GE, Ibrahim SIA. Chemical composition and the insecticidal activity of certain plants applied as powders and essential oils against two stored-products coleopteran beetles. J Pest Sci. 2011; 84:393-402.

[24] Erler F, Cetin H. Larvicidal activity of essential oil from Pimpinella anisum and its major component, trans-anethole, against Euproctis chrysorrhoea. Fres Environ Bull. 2008; 17(12 B):2170-217.

[25] Khater HF, Hanafy A, Abdel-Mageed AD, Ramadan MY, El-Madawy RS. Control of the myiasis-producing fly, Lucilia sericata, with Egyptian essential oils. Int J Dermatol. 2011; 50:187-194.

[26] Işikber AA, Özder N, Sağlam Ö: Susceptibility of eggs of Tribolium confusum, Ephestia kuehniella and Plodia interpunctella to four essential oil vapors. Phytoparasitica. 2009; 37:231-239.

[27] Erler F, Polat E, Demir H, Cetin H, Erdemir T. Control of the mushroom phorid fly, Megaselia halterata (Wood), with plant extracts. Pest Manag Sci. 2009; 65(2):144-149.

[28] Tunç I, Berger BM, Erler F, Dagli F. Ovicidal activity of essential oils from five plants against two stored-product insects. J Stored Prod Res. 2000; 36:161-168.

[29] Tort N, Honermeier B. Investigations of the ratio of methyl chavicol and trans-anethole components in essential oil of anise (Pimpinella anisum L.) from different regions of Turkey. Asian J Chem. 2005; 17: 2365-2370.

[30] Davis PH, Flora of Turkey and the East Aegean Islands, Vol. 7, Edinburgh University Press, Edinburgh 1982.

[31] Güner A, Aslan S, Ekim T, Vural M, Babaç MT. Türkiye bitkileri listesi [damarlı bitkiler]. Nezahat Gökyiğit Botanik Bahçesi ve Flora Araştırmaları Derneği Yayını. 2012; İstanbul.

[32] Cetin H, Yanikoglu A. A study of the larvicidal activity of Origanum (Labiatae) species from southwest Turkey. J Vector Ecol. 2006; 31(1):118-122.

[33] SPSS. SPSS for Windows, version 15.0. SPSS, Chicago, IL; 1999. 